\title{
Generation of a Test Reference Year for Alūksne, Latvia
}

\author{
Mārtiņš Ruduks ${ }^{1 *}$, Arturs Lešinskis ${ }^{2}$ \\ ${ }^{1}$ Department of Architecture and Building, LLU, Akadēmijas iela 19, Jelgava, LV-3001, Latvia, \\ ${ }^{2}$ Institute of Heat, Gas and Water Technology, RTU, Āzenes iela 16/20, Rīga, LV-1048, Latvija
}

\begin{abstract}
Precise and reliable meteorological data are necessary for building performance analysis. Since meteorological conditions vary significantly from year to year, there is a need to create a test reference year (TRY), to represent the long-term weather conditions over a year. In this paper two different TRY data models were generated and compared: TRY and TRY-2. Both models where created by analysing every 3-hour weather data for a 30-year period (1984-2013) in Alūksne, Latvia, provided by the Latvian Environment Geology and Meteorology Centre (LEGMC). TRY model was generated according to standard LVS EN ISO 15927-4, but to create second model - TRY-2, 30 year average data were applied. The generated TRY contains typical months from a number of different years. The data gathered from TRY and TRY-2 models where compared with the climate data from the Latvian Cabinet of Ministers regulation No. 379, Regulations Regarding Latvian Building Code LBN 003-01. Average monthly temperature values in LBN 003-01 were lower than the TRY and TRY-2 values. The results of this study may be used in building energy simulations and heating-cooling load calculations for selected region. TRY selection process should include the most recent meteorological observations and should be periodically renewed to reflect the long-term climate change.
\end{abstract}

Key words: test reference year; climate analysis, climate change, building energy simulations.

\section{Introduction}

In Latvian legislation long-term climate data is reflected in the Latvian Building Code (LBN) 00301 „Būvklimatologija” (Construction climatology), (23.08.2001, Riga), where various climatic indicators are shown that represent the climatic situation in the territory of Latvia, providing information about the average monthly and yearly meteorological parameters. But this information is not enough to fully describe the region's climatic conditions, because there is a necessity to define every day and every hour meteorological data values.

The need of such meteorological data worldwide led to the development of methodologies for generating the typical reference year (TRY) in the USA known as a typical meteorological year (TMY) (Hall et al., 1978). TMY is a data set that contains a sequence of 8760 hourly values of chosen meteorological quantities. The requirement of TMY is that it has to correspond to an average year (Skeiker, 2004). TMY provides every hour climatic parameter values, enabling to use these parameters for heating, ventilation and air conditioning (HVAC) device management and capacity optimisation.

Creation of TMY was introduced in 1978 by Hall et al. (Hall et al., 1978). For a network of stations in the United States, a representative database consisting of weather data was created. Hall's method has been used to successfully generate TMYs for a number of locations across the globe (Chan et al., 2006, Guggenberger et al., 2013, Hall et al., 1978, Jiang, 2010, Kalogirou, 2003, Lee et al., 2010, Skeiker, 2004, Skeiker, 2007, Yang et al., 2007, Zang et al., 2012, Zarinšs, 2001, Zhang, 2006).

LBN 003-01 describes climate parameters for ten cities of Latvia. These parameters have been calculated using data from 1961-1990. The aim of this research was to generate a representative climate database for one of these cities - Alūksne, by employing the method according to standard LVS EN ISO 15927-4 (Latvijas Valsts Standarts, 2005). Generation of TRY of Alūksne would provide with hourly climate data that LBN 003-01 does not provide.

Geographical data for Alūksne: latitude $57^{\circ} 26^{\prime} \mathrm{N}$; longitude $27^{\circ} 02^{\prime} \mathrm{E}$; on relatively flat surface, elevated $193 \mathrm{~m}$ above sea level. Located $160 \mathrm{~km}$ from Gulf of Riga (Fig. 1). Average year temperature $4.5^{\circ} \mathrm{C}$.

The TMY is generated using the available weather data obtained from the station of Alūksne by the Latvian Environment Geology and Meteorology Centre (LEGMC), covering the period from 19842013. LEGMAC database provides with 3-hour weather data values for the temperature and relative humidity. As TRY consists of every hour values, the necessary values are interpolated.

This is the first time in Latvia when 30-year weather data has been used to create TRY.

\footnotetext{
* Corresponding Author's email: martins.ruduks@inbox.lv
} 


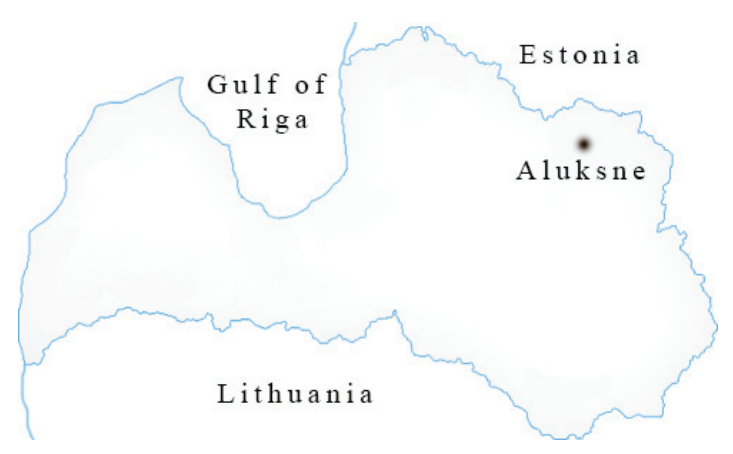

Figure 1. Location of Alūksne in Latvia.

\section{Materials and Methods}

TRY models where created applying two different TRY creation methods. TRY model was created by ISO 15927-4 (Latvijas Valsts Standarts, 2005) method. The second TMY model - TMY-2 was created by applying average meteorological year method (Skeiker, 2007). TRY model consists of weather data that have been observed in the 30 year period. This method includes temperature peaks that can be used to determine the appropriate power for HVAC systems. TMY-2 model consists of averaged 30 year weather data, this method does not show the temperature peaks, but it shows the most precise average monthly temperatures. TMY-2 model is best used for calculating average long-term building energy consumptions for HVAC systems.

\section{TRY Creation}

In this study, the ISO 15927-4 (Latvijas Valsts Standarts, 2005) method was used to construct the TRY. The primary selection was made on the basis of dry-bulb air temperature, cloud coverage (ISO 15927 4 suggest to use direct normal solar irradiance, but this parameter is not available for this station, so it was replaced with cloud coverage), and relative humidity. The wind speed was used for secondary selection. To guarantee that the selected year represents the Alūksne climate as completely as possible, 30-year weather data where applied.

Climate data for TRY creation were obtained from LEGMC database from 1984-2013. LEGMC provides climate data with 3 hour interval, but TRY needs hourly climate data. The necessary data for TRY were calculated by linear interpolation.

In February, there may be 28 or 29 days, and it is not possible to compare years with different count of days; thus, 29. February was excluded from TMY creation. The rest of the days where rearranged in ascending order starting with the first hour of January till the last hour of December (8760 values).
For each climatic parameter p (dry-bulb temperature, cloud coverage and relative humidity), daily means $\bar{p}$ are calculated. For each calendar month $\mathrm{m}$, the cumulative distribution function $\Phi_{p, m, i}$ of daily means over all the years in the data set is calculated using equation (1):

$$
\Phi_{p, m, i}=\frac{K_{i}}{N+1}
$$

where $K_{i}$ - rank order of the i-th value of the daily means within that calendar month in the whole data set;

$\mathrm{N}$ - number of days in any calendar month in the whole data set.

For each year y of the data set, the cumulative distribution function $F_{p, y, m, i}$ of the daily means within each calendar month is calculated using equation (2):

$$
F_{p, y, m, i}=\frac{J_{i}}{n+1}
$$

where $J_{i}$ - rank order of the i-th value of the daily means within that calendar month and that year; $\mathrm{n}$ - number of days in an individual month.

For each calendar month $\mathrm{m}$ the FinkelsteinSchafer statistic for parameter $\mathrm{p}, F S_{p, y, m}$ for each year $y$ of the data set is calculated using equation (3):

$$
F S_{p, y, m}=\sum_{i=1}^{n}\left|F_{p, y, m, i}-\Phi_{p, m, i}\right|
$$

To normalize $F S_{p, y, m}$ for months of varying lengths, the results of equation (3) are divided by the number of days of the month $(28,29,30$, or 31$)$. For each calendar month individual months are ranked from the multiyear record in order of increasing value of $F S_{p, y, m}$. Monthly average $F S_{p, y, m}$ values of climate parameters dry-bulb air temperature, cloud coverage and relative humidity are added together and the same months of all years are ranked in the order of the increasing value of $F S_{p, y, m}$. From each calendar month, three candidate months with the lowest total ranking are selected. The monthly deviation of the wind speed of the three months is compared with the corresponding multi-year mean of calendar months. The month with the lowest deviation in wind speed is selected as the best month for inclusion in the TRY. 
After the selection of the twelve calendar months for TRY, the months should be joined together. The first and the last eight hours of each month are adjusted by interpolation to ensure a smooth transition when months are joined to form a TRY. The adjustment also includes the last eight hours of December and the first eight hours of January, so that the test reference year can be used repeatedly in simulations (Latvijas Valsts Standarts, 2005).

\section{TRY-2 creation}

TRY-2 model was created with average meteorological year method (Skeiker, 2007). In this method the same climate data were used as it was in TRY model creation. And they were arranged starting from the first hour of January till the last hour of December. Each of the TMY-2 model 8760 drybulb temperature, relative humidity, cloud coverage and wind speed values were calculated by averaging value of every hour from 30-year data.

\section{Heating degree days (HDD)}

HDD is a parameter used in the HVAC industry to estimate heating and cooling energy requirements. HDD can be calculated using equation (4) (Buyukalaca et al., 2001):

$$
H D D=\sum_{\text {days }}\left(T_{b}-T_{m}\right)
$$

where $T_{b}$ - base temperature $\left(18^{\circ} \mathrm{C}\right)$;

$T_{m}$ - outdoor temperature (at duration of heating period);

$\sum_{\text {days }}$ - duration of heating period.

\section{Results and Discussion}

TRY was created combining months from different years based on their ability to follow the criteria described in materials and methods. Selected month/year combinations from which the TRY was created are shown in Figure 2. Two months (January and March) were selected from one year (2000), but other months were selected from different years. That displays that months were selected from all range of the observed period.

After selected months (Figure 2) were connected and TRY was created, temperature fluctuation (Figure 3), temperature distribution (Figure 5), relative humidity fluctuation (Figure 4) and relative humidity distribution (Figure 6) was displayed. Results show similar tendencies with data from Estonian TRY (Kalamees and Kurnitski, 2006).

Figures 3 and 4 show how temperature and relative humidity values change in TRY model starting from the beginning of January until the end of December.

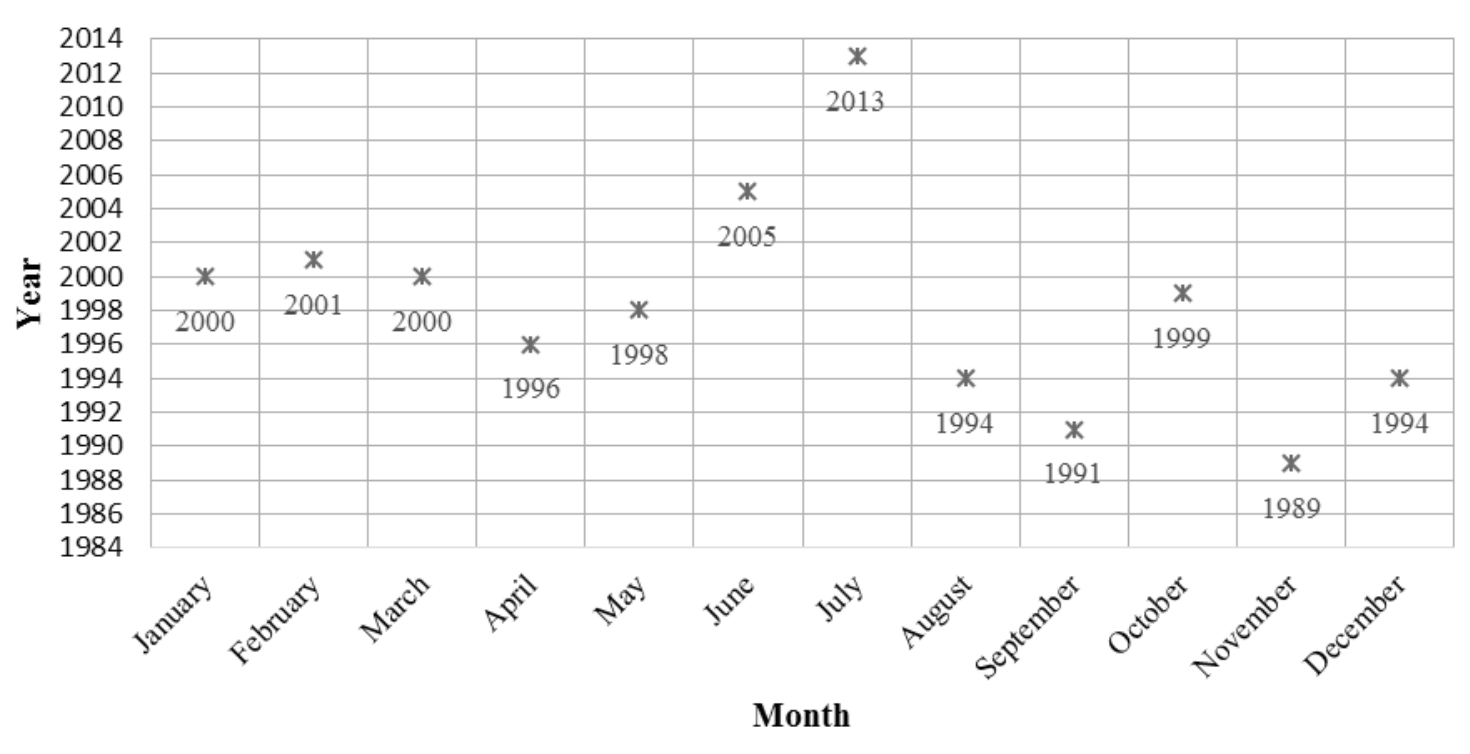

Figure 2. The month/year combinations for the composition of TRY. 


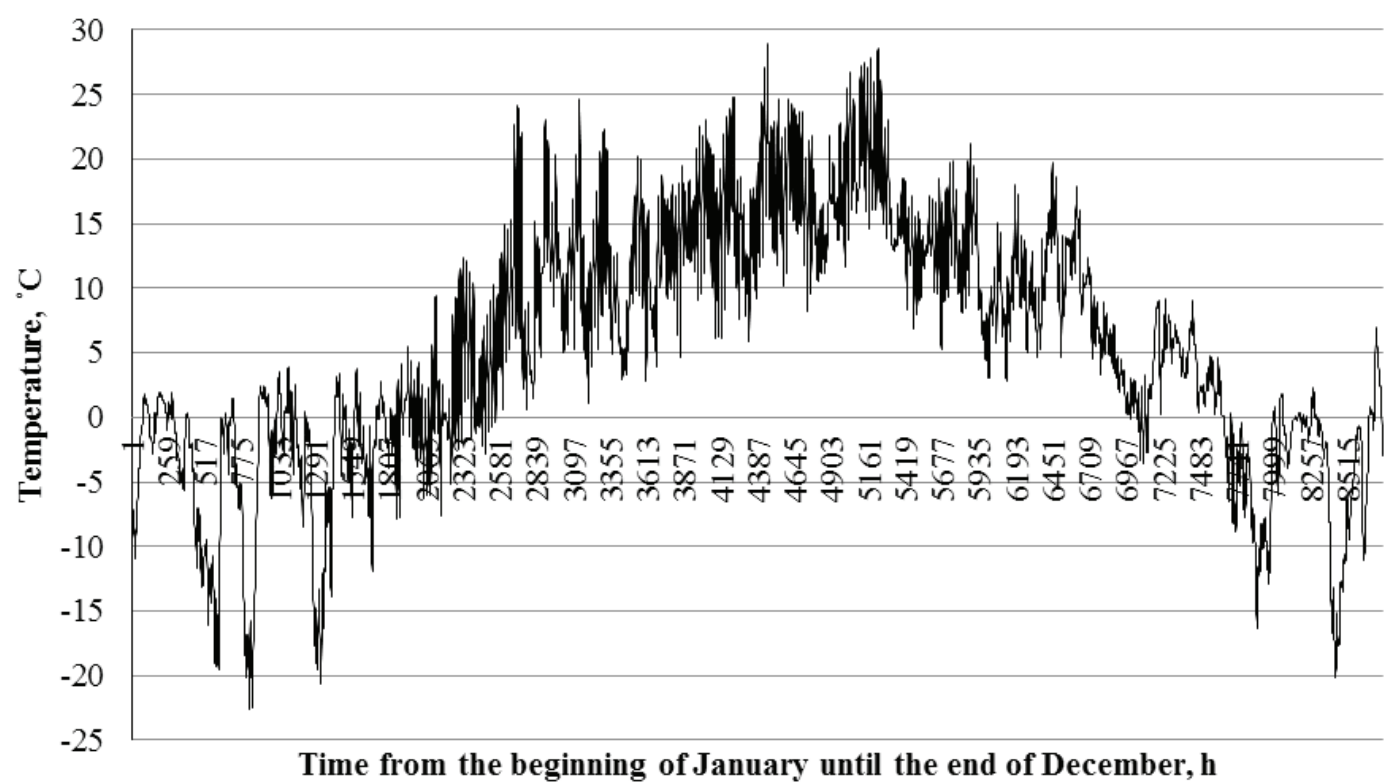

Figure 3. Temperature fluctuation in TRY.

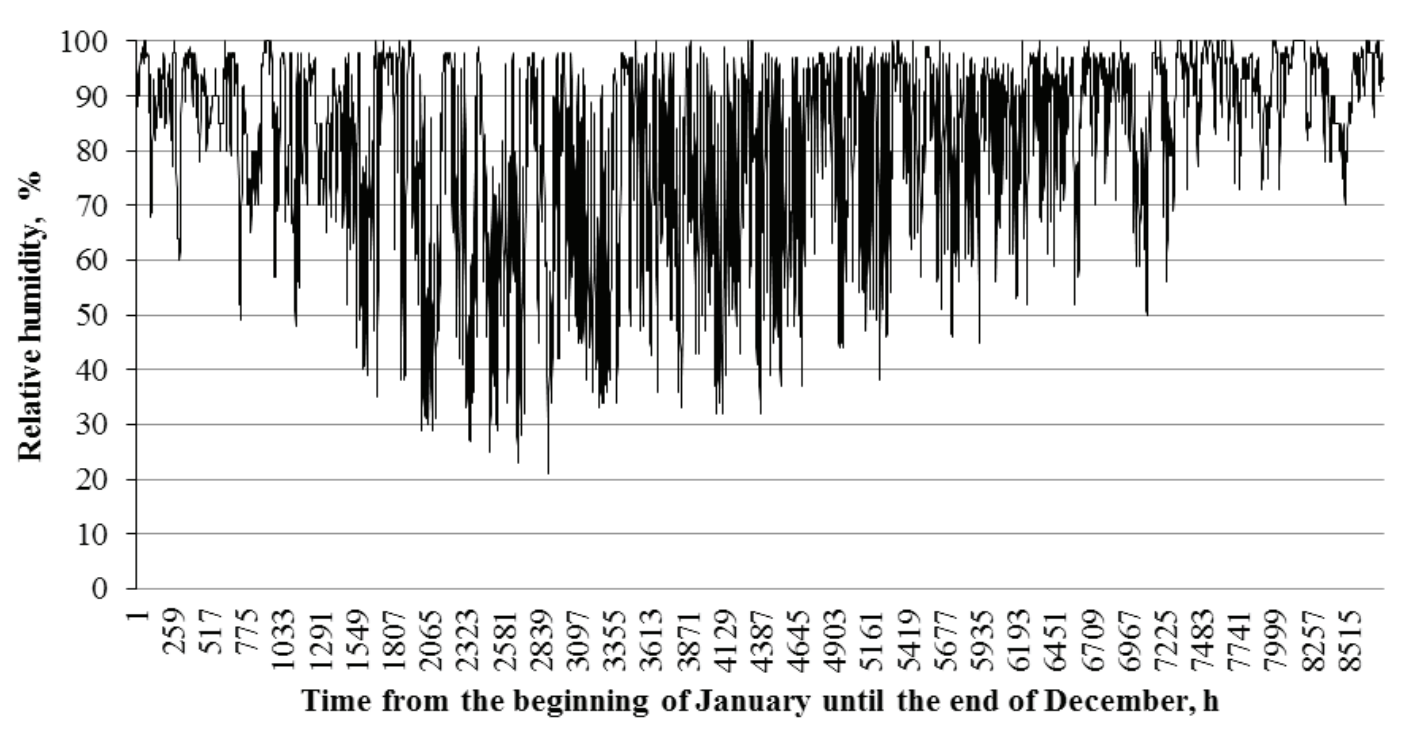

Figure 4. Relative humidity fluctuation in TMY.

When TRY and TRY-2 model temperature distribution values are compared with 30- year average data (long term data) (Figure 5), TRY model shows a good agreement with the long-term data. TRY model's maximum temperature value deviation from long-term data is 66 hours per year at $2{ }^{\circ} \mathrm{C}$, but TRY2 model's deviation at $-5^{\circ} \mathrm{C}$ is 474 hours per year. The total TRY model's temperature deviation from 30 -year average data is 1044 hours, but TRY-2 model deviation is 3592 hours. The difference between TRY and TRY-2 models can be explained by the fact that TRY-2 is made averaging climate data and it does not contain maximum and minimum temperature values, as they are averaged.

Most typical relative humidity level in TRY model is $98 \%$, it is observed for 689 hours, TRY-2 model's typical relative humidity level is $92 \%$ and it is observed for 691 hours (Figure 6). The TRY and TRY-2 model total relative humidity deviation value is 6018 hours. The large deviation can also be explained by the fact that TRY-2 model's creation method eliminates the maximum and minimum values, but TRY model has the highest observed relative humidity levels at these values (Figure 6). 


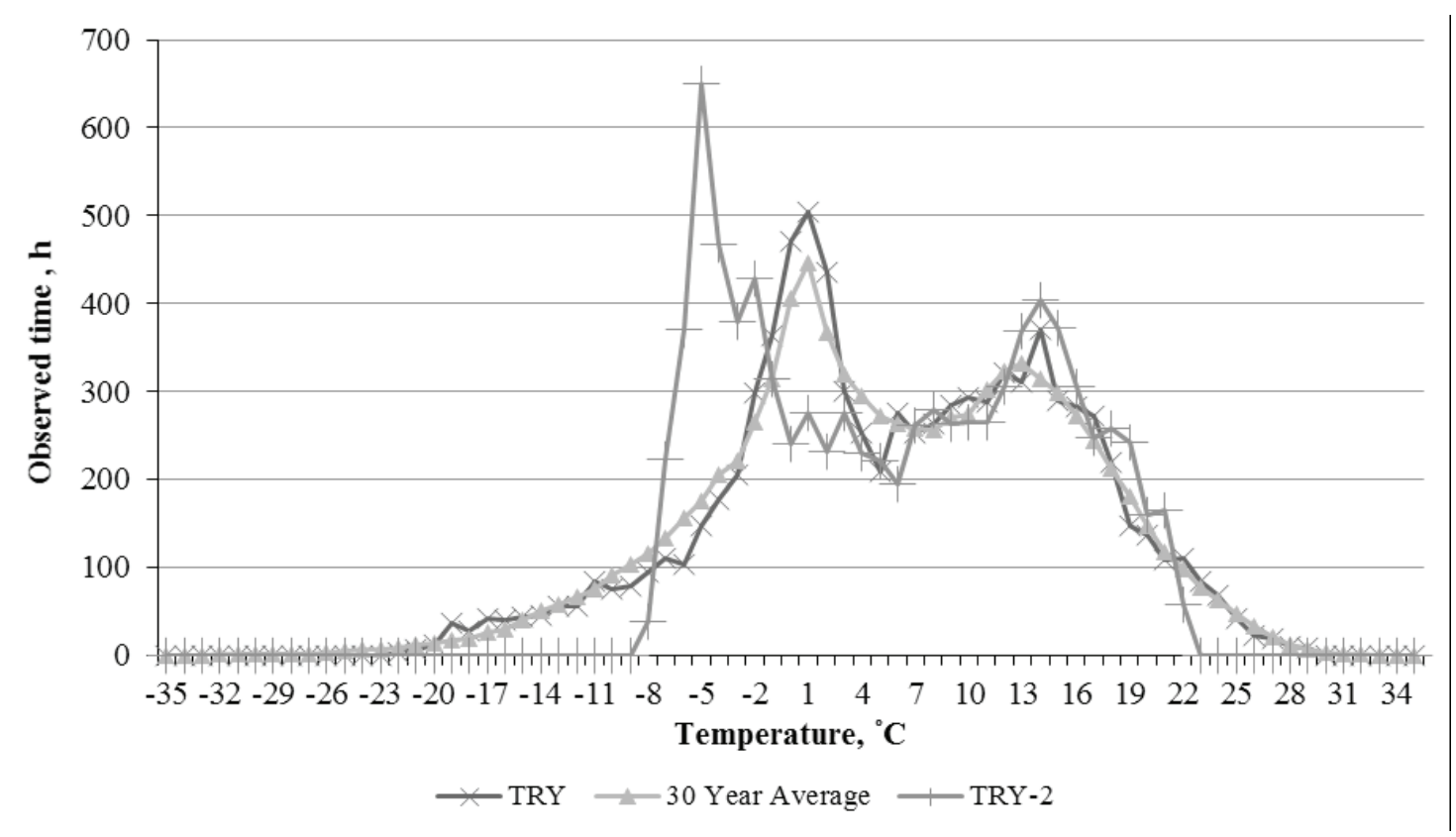

Figure 5. Hourly temperature distribution for TRY, 30-year average data and TRY-2.

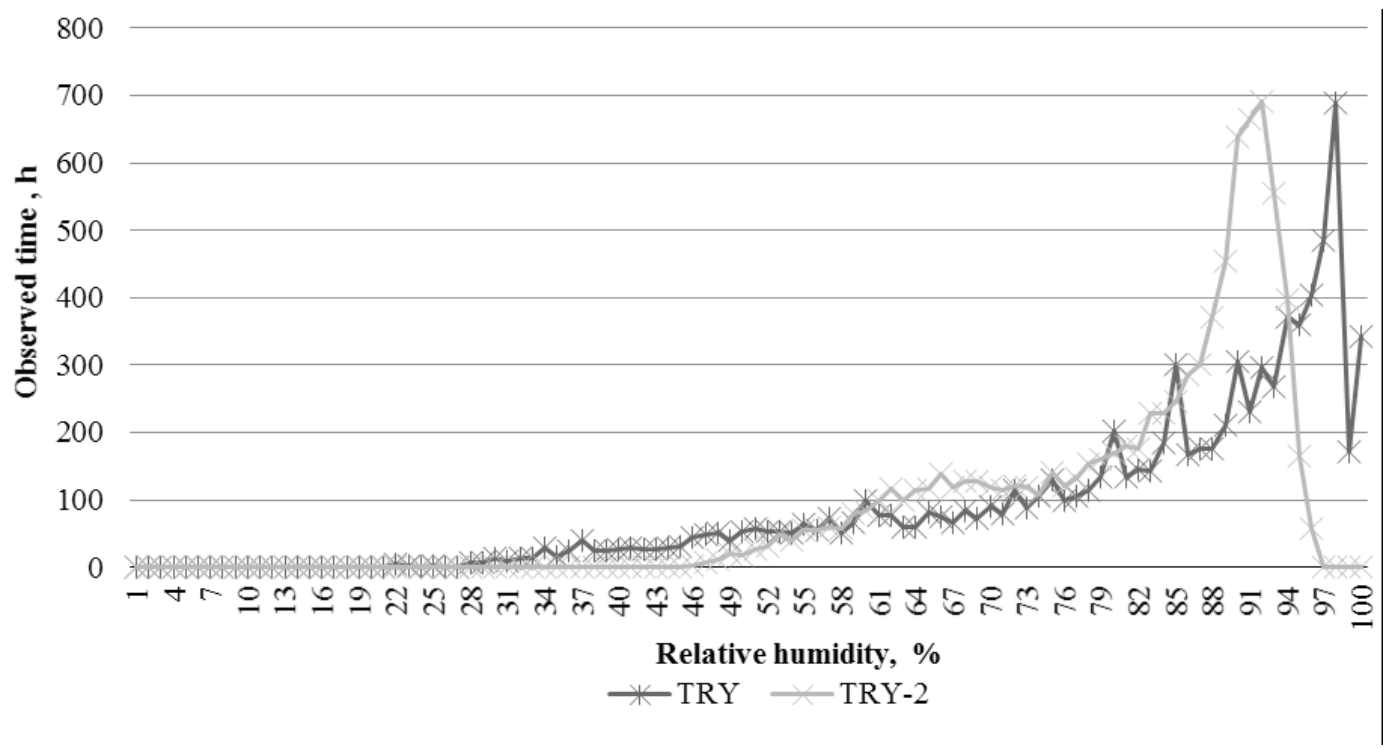

Figure 6. Relative humidity distribution for TRY and TMY-2 data.

One of the most important results that can be obtained from TRY models is shown in Figure 7 and 8 . These figures show how many hours per year each temperature and content of moisture combination can be observed. Most typical content of moisture and temperature combination in TRY model is $4 \mathrm{~g} \mathrm{~kg}^{-1}$ at $0{ }^{\circ} \mathrm{C}$ (Figure 7). This combination can be observed for 339 hours. TRY-2 model's most typical content of moisture and temperature combination is $2 \mathrm{~g} \mathrm{~kg}^{-1}$ at $-5{ }^{\circ} \mathrm{C}$ (Figure 8). This combination can be observed for 629 hours. These results can be used for HVAC system analysis and building energy simulations. Data from Figure 7 and 8 gives an ability to calculate how long it will be necesary to use heating and cooling devices for buildings in this region, and chose optimal capasity for these devices. 


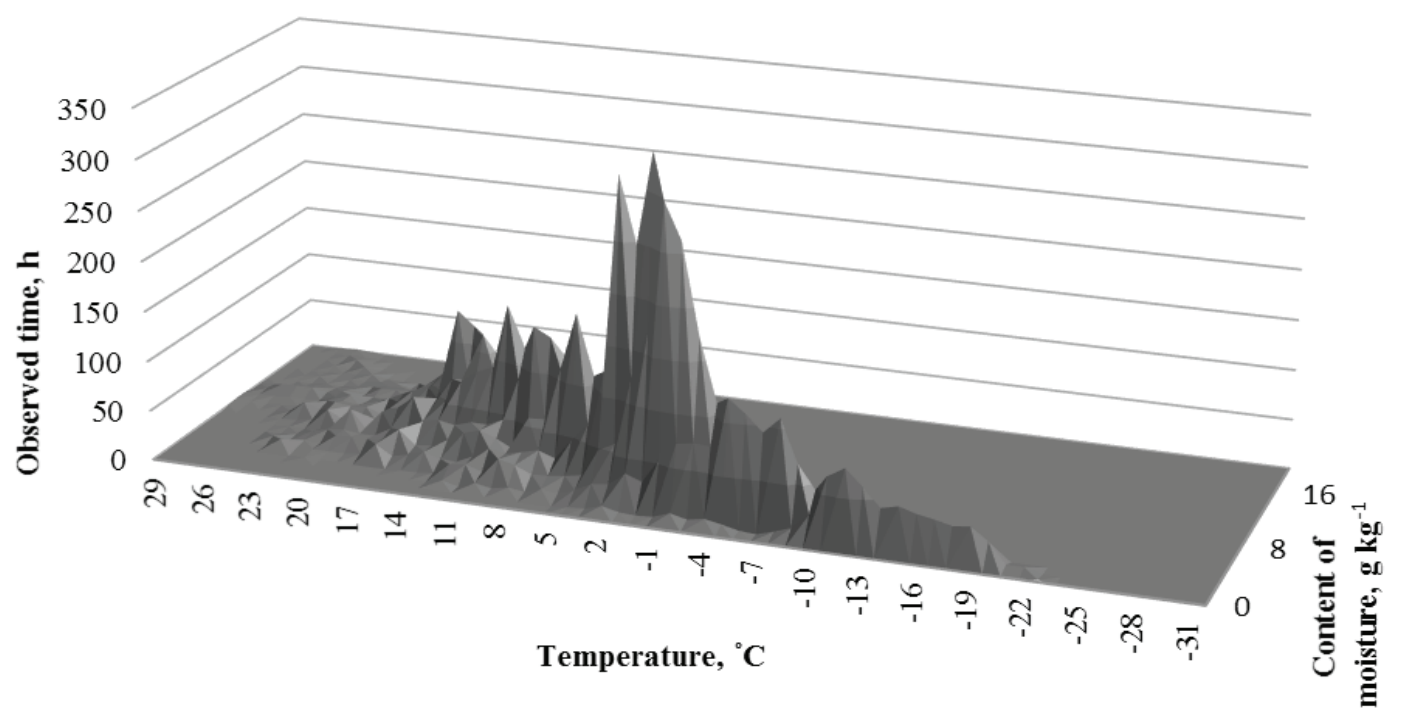

Figure 7. Combination of temperature and content of moisture for TRY.

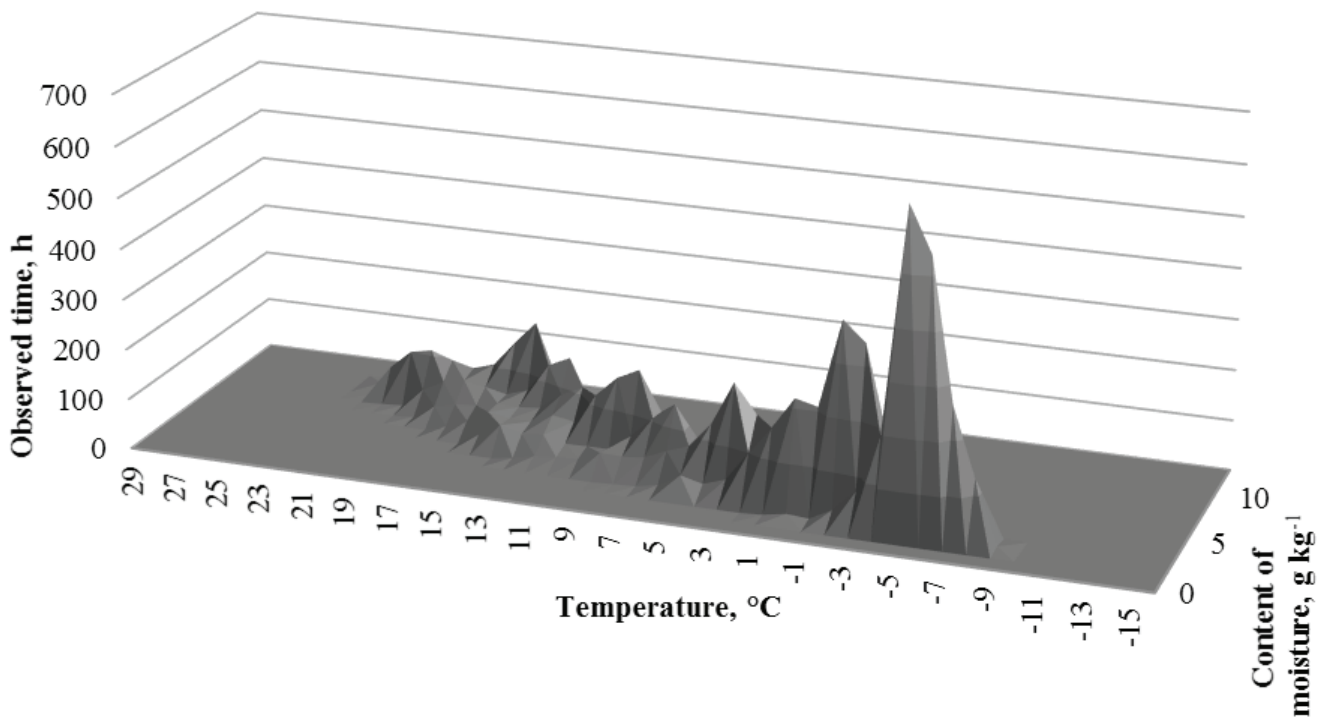

Figure 8. Combination of temperature and content of moisture for TRY-2.

Average year temperature value for TRY, TRY2 and 30 -year average data is identical $-5.4{ }^{\circ} \mathrm{C}$, but difference with LBN 003-01 value is $0.9{ }^{\circ} \mathrm{C}$ (Table 1). Average relative humidity value for TRY, TRY2 and 30 year average data is identical $-81 \%$, but difference with LBN 003-01 value is $1 \%$ (Table 2 ). The difference with LBN 003-01 value can be explained by the fact that they have been obtained from 1961-1990, but TRY and TRY-2 values were obtained from 1984-2013. The climate change can be the factor for the difference. TRY-2 model's monthly average temperature, relative humidity and wind speed values are the same as 30 year average values (Table 1, 2 and 3); it follows from the definition of TRY-2 creation method. 
Average monthly temperature values $\left({ }^{\circ} \mathrm{C}\right)$

Table 1

\begin{tabular}{cccccccc}
\hline Month & Jan & Feb & Mar & Apr & May & Jun & Jul \\
\hline 30 year average & -5.4 & -6.0 & -1.5 & 5.4 & 11.3 & 14.9 & 17.3 \\
TRY & -4.2 & -6.2 & -0.9 & 5.8 & 11.7 & 14.3 & 17.5 \\
TRY-2 & -5.4 & -6.0 & -1.5 & 5.4 & 11.3 & 14.9 & 17.3 \\
LBN 003-01 & -7.6 & -6.8 & -2.5 & 4.0 & 11.0 & 14.8 & 16.1 \\
Month & Aug & Sep & Oct & Nov & Dec & \multicolumn{2}{c}{ Average } \\
\hline 30 year average & 15.7 & 10.5 & 5.4 & -0.2 & -4.0 & \multicolumn{2}{c}{5.4} \\
TRY & 15.5 & 10.6 & 5.8 & -1.3 & -3.6 & \multicolumn{2}{c}{5.4} \\
TRY-2 & 15.7 & 10.5 & 5.4 & -0.2 & -4.0 & \multicolumn{2}{c}{5.4} \\
LBN 003-01 & 15.0 & 10.2 & 5.2 & -0.4 & -4.9 & \multicolumn{2}{c}{4.5} \\
\hline
\end{tabular}

Table 2

Average monthly relative humidity value (\%) comparison from January to December

\begin{tabular}{cccccccccccccc}
\hline Month & Jan & Feb & Mar & Apr & May & Jun & Jul & Aug & Sep & Oct & Nov & Dec & Average \\
\hline 30 year average & 90 & 86 & 78 & 69 & 68 & 74 & 76 & 80 & 84 & 87 & 91 & 91 & 81 \\
TRY & 89 & 83 & 76 & 69 & 69 & 73 & 78 & 82 & 85 & 87 & 93 & 93 & 81 \\
TRY-2 & 90 & 86 & 78 & 69 & 68 & 74 & 76 & 80 & 84 & 87 & 91 & 91 & 81 \\
LBN 003-01 & 87 & 84 & 78 & 71 & 68 & 71 & 75 & 79 & 84 & 87 & 90 & 90 & 80 \\
\hline
\end{tabular}

Average year wind speed value for TRY, TRY-2 and 30-year average data is identical $-2.6 \mathrm{~m} \mathrm{~s}^{-1}$, but difference with LBN 003-01 value is $0.1 \mathrm{~m} \mathrm{~s}^{-1}$ (Table 3).

Average monthly wind speed values $\left(\mathrm{m} \mathrm{s}^{-1}\right)$

Table 3

\begin{tabular}{cccccccc}
\hline Month & Jan & Feb & Mar & Apr & May & Jun & Jul \\
\hline 30 year average & 3.0 & 2.8 & 2.8 & 2.6 & 2.4 & 2.2 & 2.0 \\
TRY & 2.9 & 2.8 & 3.2 & 2.2 & 2.4 & 2.2 & 2.1 \\
TRY-2 & 3.0 & 2.8 & 2.8 & 2.6 & 2.4 & 2.2 & 2.0 \\
LBN 003-01 & 3.1 & 3.0 & 2.9 & 2.7 & 2.4 & 2.3 & 2.1 \\
Month & Aug & Sep & Oct & Nov & Dec & Average \\
\hline 30 year average & 2.1 & 2.3 & 2.7 & 2.9 & 3.0 & 2.6 \\
TRY & 2.1 & 2.5 & 2.6 & 3.0 & 3.2 & 2.6 \\
TRY-2 & 2.1 & 2.3 & 2.7 & 2.9 & 3.0 & 2.6 \\
LBN 003-01 & 2.2 & 2.6 & 2.9 & 3.1 & 3.0 & 2.7 \\
\hline
\end{tabular}

Comparing TRY, TRY-2 and LBN 003-01 values (Table 4) LBN 003-01 has the longest duration of heating period, the lowest average temperature in heating period and also it has the greatest number of degree days. All these parameters show the impact of increased average temperature value (Table 1). 
Table 4

Summary of climate parameters

\begin{tabular}{lccc}
\hline \multicolumn{1}{c}{ Parameter } & TRY & TRY-2 & LBN 003-01 \\
\hline Maximum temperature, ${ }^{\circ} \mathrm{C}$ & 29.0 & 21.9 & 31.1 \\
Minimum temperature, ${ }^{\circ} \mathrm{C}$ & -22.6 & -8.8 & -32.7 \\
Duration of heating period, days & 202 & 200 & 214 \\
Average temperature in heating period, ${ }^{\circ} \mathrm{C}$ & -1.2 & -1.4 & -1.9 \\
Number of heating degree days (HDD) & 3875 & 3883 & 4259 \\
\hline
\end{tabular}

It is hard to directly compare results from this research with similar researches because every location has different climate parameters. Comparing results in Table 4 with the results that were obtained by Zariņš (Zariņš, 2001) for Riga city, they show similar tendency that average monthly temperatures in LBN 003-01 are lower than the TRY values. Results can be explained by the fact that data in LBN 003-01 are obtained from 1961-1990, but for TRY from 19842013. Due to the global changes, the average monthly temperatures have risen.

\section{Conclusions}

The aim of this research was to generate TRY for Alūksne and it was generated based on the most recent 30-year (1984-2013) climate data. The generation of a TRY is very useful for optimal HVAC system design and building energy simulations. With every hour climate data, provided by TRY, it is possible to make building energy simulations and make calculations to determine necessary power for HVAC devices that was not possible with data from LBN 003-01.

Comparing TRY and TRY-2 model values with LBN 003-01 ones, they showed deviation of some weather parameters that can be explained with climate changes. These differences show that there is a need for TRY creation and the latest possible climate data should be used. In this paper TRY is created for one city of Latvia, but results suggest that the research needs to be continued, and TRY models need to be generated for all 10 cities that are described in LBN 003-01.

TRY-2 model consists of averaged 30-year weather data, this method does not show the temperature peaks, but it shows the most precise average monthly temperatures. TRY-2 model is best used for calculating average long-term building energy consumptions for HVAC systems. TRY model is used if there is a necessity for temperature peak values and to determine the necessary power for HVAC systems to operate at these temperatures.
Mostly this parameter is very important and TRY model is used in most of calculations.

\section{References}

1. Buyukalaca, O., Bulut, H., Yilmaz, T. (2001). Analysis of variable-base heating and cooling degree-days for Turkey. Applied Energy 69(4), 269-283. DOI: 10.1016/S0306-2619(01)000174.

2. Chan, A.L.S., Chow, T.T., Fong, S.K.F., Lin, J.Z. (2006). Generation of a typical meteorological year for Hong Kong. Energy Conversion and Management. 47(1), 87-96. DOI: 10.1016/j. enconman.2005.02.010.

3. Guggenberger, J.D., Elemore, A.C., Crow, M.L. (2013). Predicting performance of a renewable energy-powered microgrid throughout the United States using typical meteorological year 3 data. Renewable Energy. 55, 189-195. DOI: 10.1016/j.renene.2012.12.001.

4. Hall, I.J., Prairie, R.R., Anderson, H.E., Boes, E.C. (1978). Generation of a typical meteorological year. In Annual Meeting of the American Section of the International Solar Energy Society, 28 - 31 August (pp. 669-671). Denver, Colorado, USA: American Section of the International Solar Energy Society.

5. Jiang, Y. (2010). Generation of typical meteorological year for different climates of China. Energy. 35(5), 1946-1953. DOI: 10.1016/j.energy.2010.01.009.

6. Kalamees, T. and Kurnitski, J. (2006). Estonian Test Reference Year for Energy Calculations. In proceedings of the Estonian Academy of Science, Engineering, March 2006 (pp.4058.). Tallina, Estonia: Estonian Academy of Sciences.

7. Kalogirou, S.A. (2003). Generation of typical meteorological year (TMY-2) for Nicosia, Cyprus. Renewable Energy. 28(15), 2317-2334. DOI: 10.1016/S0960-1481(03)00131-9. 
8. Latvijas Valsts Standarts. (Latvia State Standard) (2005). Ēku hidrotermiskie raksturlielumi. Klimatisko raksturlielumu aprēķināšana un izteikšana. 4. daḷa: Ikstundas dati apkures un dzesēšanas ikgadējā enerğijas patēriņa novērtēšanai. (Hygrothermal performance of buildings - Calculation and presentation of climatic - Part 4: Hourly data for assessing the annual energy use for heating and cooling). LVS EN ISO 15927-4. Rīga(in Latvian).

9. Lee, K., Yoo, H., Levermore, G.J. (2010). Generation of typical weather data using the ISO Test Reference Year (TRY) method for major cities of South Korea. Building and Environment. 45(4), 956-963. DOI: 10.1016/j. buildenv.2009.10.002.

10. Skeiker, K. (2004). Generation of a typical meteorological year for Damascus zone using the Filkenstein-Schafer statistical method. Energy Conversion and Management. 45(1), 99112. DOI: 10.1016/S0196-8904(03)00106-7.

11. Skeiker, K. (2007). Comparison of methodologies for TMY generation using
10 years data for Damascus, Syria. Energy Conversion and Management. 48(7), 20902102. DOI: 10.1016/j.enconman.2006.12.014.

12. Yang, L., Lam, J.C, Liu, J. (2007). Analysis of typical meteorological years in different climates of China. Energy Conversion and Management. 48(2), 654-668. DOI: 10.1016/j. enconman.2006.05.016.

13. Zang, H., Xu, Q., Biang, H. (2012). Generation of typical solar radiation data for different climates of China. Energy. 38(1), 236-248. DOI: 10.1016/j.energy.2011.12.008.

14. Zarinš̌, M. (2001). Klimata datu izvēle gaisa kondicionēšanas jaudas aprēķinam. (Climate Data Choice to Calculate Air Conditioning Capacity) Master thesis, Latvia University of Agriculture, Jelgava, Latvia. (in Latvian).

15. Zhang, Q. (2006). Development of the typical meteorological database for Chinese locations. Energy and Buildings. 38(11), 1320-1326. DOI: 10.1016/j.enbuild.2006.04.003. 